Int. J. Electrochem. Sci., 11 (2016) 2994 - 3006

\title{
Electrochemical Evaluation of a Stainless Steel as Reinforcement in Sustainable Concrete Exposed to Chlorides
}

\author{
G. Santiago-Hurtado ${ }^{1}$, M.A. Baltazar-Zamora ${ }^{2, *}$, J. Olguin-Coca ${ }^{3}$, L. D. López L ${ }^{3}$, \\ R. Galván-Martínez ${ }^{4}$, A. Ríos-Juárez ${ }^{5}$, C. Gaona-Tiburcio ${ }^{6}$, F. Almeraya-Calderón ${ }^{6}$ \\ ${ }^{1}$ Doctorado en Ingeniería, FIME, Xalapa, Universidad Veracruzana, Veracruz, México. \\ ${ }^{2}$ Facultad de Ingeniería Civil - Xalapa, Universidad Veracruzana, Circ. G. Aguirre Beltrán S/N, \\ Lomas del Estadio, CP. 91000, Xalapa, Veracruz, México. \\ ${ }^{3}$ Grupo de Investigación DICSO, Instituto de Ciencias Básicas e Ingeniería, UAEH \\ ${ }^{4}$ Instituto de Ingeniería - Boca del Rio, Ver; Universidad Veracruzana. \\ ${ }^{5}$ CAPUFE-Delegación Regional VII Veracruz, Boca del Río, Veracruz, México. \\ ${ }^{6}$ Universidad Autónoma de Nuevo León. FIME. Centro de Investigación e Innovación en Ingeniería \\ Aeronáutica, CIIIA, Carretera a Salinas Victoria Km. 2.3. C.P. 66600. Apocada. Nuevo León. México \\ *E-mail: $\underline{\text { mbaltazar@uv.mx }}$
}

doi: $10.20964 / 110402994$

Received: 11 September 2015 / Accepted: 8 February 2016 / Published: 1 March 2016

Corrosion of steel reinforcement is one of the top three causes of deterioration of reinforced concrete structures. For this research three concrete mixtures were produced, the first concrete was made with $100 \%$ cement CPC 30R, the second mixture was considered sustainable concrete because using $80 \%$ of cement CPC 30R and $20 \%$ of silica fume and the third mixture was elaborated with $80 \%$ of cement CPC 30R and $20 \%$ of fly ash, these mixtures were designed according to the method ACI 211.1, in the specimens were embedded bars of AISI 304 stainless steel and AISI 1018 steel, the specimens were exposed in a solution at $3.5 \%$ of $\mathrm{NaCl}$, simulating a marine environment, for to evaluate the corrosion resistance were used electrochemical techniques of Half-Cell Potential, standard ASTM C-876-09 and the Linear Polarization Resistance, standard ASTM G59, results $\mathrm{E}_{\text {corr }}$ and $\mathrm{I}_{\text {corr }}$ after 180 days of exposure show that, the best performance was presented concrete specimens produced with $20 \%$ silica fume and reinforced with AISI 304 stainless steel, with corrosion potential $\left(\mathrm{E}_{\mathrm{corr}}\right)$ indicating a $10 \%$ probability of corrosion and $\mathrm{I}_{\text {corr }}$ values that indicate a passivity level of corrosion.

Keywords: Sustainable Concrete, Corrosion, Marine Environment, Fly Ash, Silica Fume

\section{$\underline{\text { FULL TEXT }}$}

(C) 2016 The Authors. Published by ESG (www.electrochemsci.org). This article is an open access article distributed under the terms and conditions of the Creative Commons Attribution license (http://creativecommons.org/licenses/by/4.0/). 